\title{
Dissecting the role of guanidine copper complexes in atom transfer radical polymerization by density functional theory
}

\author{
S Herres-Pawlis ${ }^{1 *}$, Haase $^{2}$, O Bienemann ${ }^{1}$ \\ From 6th German Conference on Chemoinformatics, GCC 2010 \\ Goslar, Germany. 7-9 November 2010
}

Since the development of the living / controlled radical polymerization method ATRP (= atom transfer radical polymerization) in 1995 [1] new catalysts for this reaction have been intensively investigated. This method conquered rapidly numerous fields in chemistry ranging from organic and polymer synthesis to materials science and nanotechnology.

Guanidine copper complexes display high activity in ATRP of styrene but the factors imposed on the activator/deactivator equilibrium are multifaceted [2]. Herein we report on new copper complexes with the guanidine ligand 1,3,3-tetramethyl-2-(quinolin-8-yl)guanidine which produce polystyrene with a narrow weight distribution and in high yields. Kinetic studies showed that the polymerization is of living character. Structural characterization leads us to a proposal for the activator and deactivator structures which control the ATRP (Figure 1). By density functional theory, we were able to dissect the influences on the position of the equilibrium between the $\mathrm{Cu}(\mathrm{I})$ and $\mathrm{Cu}(\mathrm{II})$ complex (ligand donor strength, halogene bond strength, redox potential, coordinative space) operating the polymerization process.

\section{Author details}

${ }^{1}$ Fakultät Chemie, Technische University of Dortmund, 44221 Dortmund, Germany. ${ }^{2}$ Department of Chemistry, University of Paderborn, 33098

Paderborn, Germany.

Published: 19 April 2011

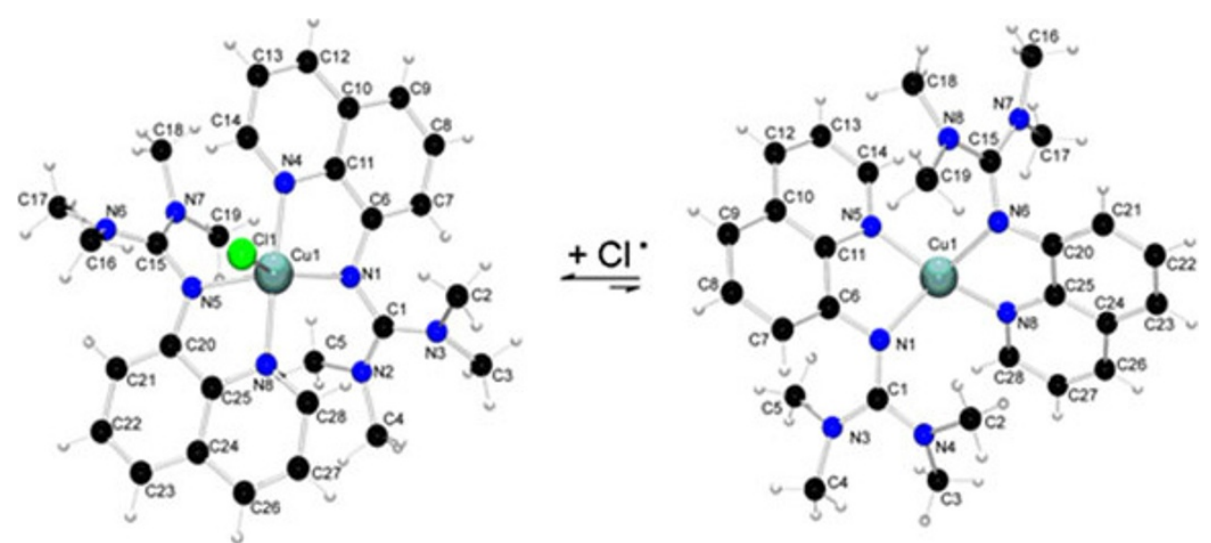

Figure 1 Activator/deactivator equilibrium in ATRP.

\footnotetext{
* Correspondence: sonja.herres-pawlis@tu-dortmund.de

'Fakultät Chemie, Technische University of Dortmund, 44221 Dortmund,

Germany

Full list of author information is available at the end of the article
} 


\section{References}

1. Wang J-S, Matyjaszewski K: Controlled Radical Polymerization. Atom Transfer Radical Polymerization in the Presence of Transition Metal Complexes. J Am Chem Soc 1995, 117:5614-5615.

2. Bienemann O, Haase R, Flörke U, Döring A, Kuckling D, Herres-Pawlis S: Neue Bisguanidin-Kupfer-Komplexe und ihre Anwendung in der ATRP. Z Naturforsch 2010, 65b:798-806.

doi:10.1186/1758-2946-3-S1-P28

Cite this article as: Herres-Pawlis et al: Dissecting the role of guanidine copper complexes in atom transfer radical polymerization by density functional theory. Journal of Cheminformatics 2011 3(Suppl 1):P28.

\section{Publish with ChemistryCentral and every scientist can read your work free of charge}

"Open access provides opportunities to our colleagues in other parts of the globe, by allowing anyone to view the content free of charge."

W. Jeffery Hurst, The Hershey Company.

- available free of charge to the entire scientific community

- peer reviewed and published immediately upon acceptance

- cited in PubMed and archived on PubMed Central

- yours - you keep the copyright

Submit your manuscript here:

http://www.chemistrycentral.com/manuscript/<smiles>c1ccccc1</smiles> 